\title{
Resiliensi terhadap Tekanan Pekerjaan Pada Staf Lapangan Perusahaan Konstruksi di Surabaya
}

\author{
Siti Aminah ${ }^{1}$, Dyan Evita Santi ${ }^{2}$ \\ ${ }^{1}$ Magister Psikologi, Fakultas Psikologi Universitas 17 Agustus 1945 Surabaya \\ ${ }^{2}$ Fakultas Psikologi Universitas 17 Agustus 1945 Surabaya \\ ${ }^{1}$ Email: sitiaminah_s2@untag-sby.ac.id \\ 2Email: dyanevita@untag-sby.ac.id
}

\begin{abstract}
ABSTRAK
Pembangunan infrastruktur di era milenial saat ini sangat pesat. Pencapaian pembangunan infrastruktur yang sukses sangat dipengaruhi oleh sumber daya manusia yang berkualitas. Penelitian ini bertujuan untuk memperoleh gambaran tentang resiliensi para staf lapangan dalam menghadapi tekanan pekerjaan. Penelitian ini menggunakan metode pendekatan kualitatif dengan rancangan studi kasus. Metode pengumpulan data dalam penelitian ini menggunakan metode wawancara (analisa studi deskriptif). Subjek penelitian adalah staf lapangan perusahaan konstruksi. Wawancara dilakukan dengan merujuk pada 7 faktor resiliensi, yaitu: emotional regulation, impulse control, emphaty, optimism, causal analysis, self-efficacy dan reaching-out. Hasil penelitian menunjukkan bahwa partisipan dalam penelitian ini memiliki resiliensi terutama dalam hal emotional regulation, causal analysis, dan emphaty. Akan tetapi, partisipan masih kurang bisa mengendalikan impuls dalam proyek, kemudian kurang optimis dalam menyelesaikan pekerjaan dikarenakan banyak faktor yang mempengaruhi berjalannya suatu proyek salah satunya material. Partisipan juga masih kurang dalam efikasi diri dan pencapaian diri mereka ke depannya.
\end{abstract}

Kata kunci : resiliensi staf lapangan, kontraktor

\section{Resilience of Job Pressure of the Field Staff of Construction Company in Surabaya}

\begin{abstract}
Infrastructure development in the millennial era is currently very rapid. Achievement of successful infrastructure development is strongly influenced by quality human resources. This study aims to obtain a description of the resilience of field staff in the face of work pressure. This research uses a qualitative approach with a case study design. Data collection methods in this study used the interview method (descriptive study analysis). Subjects of research are field staff of construction companies. Interviews were conducted with reference to seven resilience factors, such as: emotional regulation, impulse control, empathy, optimism, causal analysis, self-efficacy and reaching-out. The results showed that participants in this study had resilience, especially in terms of emotional regulation,
\end{abstract}


PSISULA: Prosiding Berkala Psikologi

Vol. 1, 2019

E-ISSN: 2715-002X

causal analysis, and empathy. However, participants are still less able to control impulses in the project, then less optimistic in completing work because there are many factors that affect the running of a project, one of which is material. Participants also lacked self-efficacy and reaching-out in the future.

Keywords: resilience of field staff, contractors

\section{Pendahuluan}

Stres kerja merupakan kondisi dimana tuntutan terhadap pekerjaan melebihi kemampuan dari karyawan sehingga mengakibatkan berbagai reaksi negatif terhadap fisik, psikologis, maupun perilaku karyawan (Martel, 2005). Stres lebih sering dikaitkan dengan tuntutan (demand) dan sumberdaya (resource). Tuntutan (demand) tersebut antara lain: tanggung jawab, tekanan, kewajiban, dan bahkan ketidakpastian yang dihadapi para individu di tempat kerja (Prasetyono, 2015).

Karyawan kontraktor perusahaan konstruksi berkemungkinan mengalami stres kerja karena proyek konstruksi merupakan suatu kegiatan yang berlangsung dalam waktu yang terbatas dengan sumberdaya tertentu untuk mendapatkan hasil konstruksi dengan standar kualitas baik. Sumber daya manusia merupakan faktor penting pada pelaksanaan proyek konstruksi. Hal ini dikarenakan peran sumber daya manusia sangat dominan karena SDM merupakan motor penggerak paling utama di dalam pekerjaan proyek konstruksi. Luthfan Atmaji juga menyebutkan bahwa SDM menjadi motor utama organisasi dalam menjalankan segala kegiatannya dalam upaya mencapai tujuan (Atmaji, 2011). Pendapat itu didukung oleh Simamora dalam Purwanty dkk (2011) bahwa SDM adalah faktor sentral dalam organisasi. Kinerja manusia merupakan faktor kritis dalam menentukan kinerja organisasi (Sawitri dkk, 2007). Jadi kualitas SDM menjadi faktor penentu keberhasilan suatu proyek, dengan memiliki kualitas sumber daya manusia yang baik maka produktivitas perusahaan semakin tinggi (Rachman, 2011). Dengan demikian perhatian serius terhadap pengelolaan SDM adalah salah satu faktor penentu keberhasilan proyek konstruksi yang mutlak diperlukan (Prasetyono, 2015).

Dipresentasikan dalam Seminar Nasional "Membangun Resiliensi di Era Revolusi Industri 4.0"

Fakultas Psikologi Unissula, 22 September 2019 
PSISULA: Prosiding Berkala Psikologi

Vol. 1, 2019

E-ISSN: 2715-002X

Adapun dampak dari stres kerja dikelompokkan menjadi tiga kategori umum: (1) gejala fisiologis, (2) gejala psikologis, dan (3) gejala perilaku (Robbins dan Judge, 2011). Gejala fisiologis yang dapat terjadi akibat dari stres dapat berupa peningkatan detak jantung, sakit kepala, bahkan memicu serangan jantung. Gejala psikologis yang dipicu oleh stres dapat menyebabkan ketidakpuasan kerja, ketegangan, kecemasan, kejengkelan, kejenuhan dan sikap suka menunda-nunda pekerjaan. Di samping itu, gejala-gejala stres juga berdampak terhadap perilaku karyawan yang meliputi menurunnya tingkat produktivitas, kemangkiran, tingkat keluar karyawan yang tinggi, perubahan dalam kebiasaan makan, pola merokok, dan ketidakteraturan waktu tidur.

Stres dapat menyebabkan kecelakaan kerja karena ketika mengalami stres karyawan saat bekerja tidak dapat berkonsentrasi dengan baik. Tidak berkonsentrasi bahkan melamun dalam bekerja dapat mengakibatkan resiko jatuh, resiko terperosok, resiko tersandung, dsb (http://nusa7.com/). Kenyataannya di Indonesia tingkat kecelakaan kerja dan berbagai ancaman keselamatan dan kesehatan kerja (K3) masih cukup tinggi terutama pada sektor jasa konstruksi. Berdasarkan laporan International Labor Organitation (ILO), setiap hari terjadi kecelakaan kerja yang mengakibatkan korban fatal sebanyak 6.000 kasus. Sementara di Indonesia setiap 100 ribu tenaga kerja terdapat 20 orang fatal akibat kecelakaan kerja (https://www.republika.co.id/).

Wali kota Surabaya Tri Rismaharini pada tanggal 03/01/2014, mengakui banyak proyek fisik yang pengerjaannya molor tidak sesuai kontrak. Bahkan tidak sedikit yang ditinggal kontraktornya (http://www.mappijatim.or.id/). Kemudian terdapat beberapa kontraktor harus menerima konsekuensi berupa blacklist. Dari fakta tersebut ada kemungkinan bahwa kontraktor di Surabaya mengalami stres kerja (Prasetyono, 2015).

Dalam penelitian Septiani dan Fitria (2016) menyimpulkan bahwa individu yang mempunyai resiliensi baik akan memiliki stres yang lebih rendah. Sebaliknya, individu yang menunjukkan angka stres yang tinggi adalah individu yang cenderung 
PSISULA: Prosiding Berkala Psikologi

Vol. 1, 2019

E-ISSN: 2715-002X

kurang resilien. Penelitian tersebut mengungkap sebuah fakta bahwa stres kerja bisa dilihat dari tingkat resiliensi seseorang.

Orang yang resiliensinya tinggi tahu bagaimana ia harus menghadapi suatu masalah dan dapat menemukan cara penyelesaiannya. Mereka tetap berkembang meskipun lingkungan berubah terus-menerus, karena mereka fleksibel, cerdas, kreatif, cepat beradaptasi serta belajar dari pengalaman (Prihastuti, 2011).

Berdasar latar belakang di atas, peneliti tertarik untuk mengetahui tingkat resiliensi staf lapangan di salah satu perusahaan jasa konstruksi di Surabaya apabila diberi tekanan pekerjaan. Hal ini sangat bermanfaat dikarenakan SDM sangatlah penting dalam pembangunan suatu usaha konstruksi, di samping biaya dan material. Sumber daya yang berkualitas dan resilien akan sangat mempengaruhi tercapainya kesuksesan pembangunan.

Grotberg (1999) mendefinisikan resiliensi sebagai kemampuan yang dimiliki oleh manusia untuk menghadapi, mengatasi, mempelajari kesulitan dalam hidup dan belajar dari pengalaman dari kondisi yang tidak menyenangkan yang pernah dialaminya (Desmita, 2005, hal. 227). Menurut Grotberg, setiap individu memiliki kualitas resiliensi yang berbeda. Kualitas tersebut ditentukan oleh tingkat usia, taraf perkembangan, intensitas ketika berhadapan dengan situasi-situasi yang tidak menyenangkan serta besarnya dukungan sosial dalam membentuk resiliensi individu tersebut (Desmita, 2005, hal. 229).

Menurut Reivich dan Shatte, resiliensi merupakan kemampuan individu untuk mengatasi dan meningkatkan ketahanan diri terhadap situasi yang menekan seperti kehilangan pekerjaan, kegagalan dalam berhubungan sosial, dan bahkan trauma yang terjadi dalam hidupnya (Shatte, 2002, hal. 1). Garmezy dkk menggambarkan resiliensi sebagai kapasitas yang dimiliki individu untuk mencapai kesuksesan beradaptasi dalam menghadapi kesulitan (McCubbin, 2001, hal. 4).

Reivich dan Shatte (2002) menyebutkan tujuh faktor yang dapat membentuk resiliensi, yaitu: (a) Emotion regulation, kemampuan yang dimiliki oleh setiap individu untuk tetap tenang walaupun berada di bawah kondisi yang menekan hidupnya; (b) Impulsive control, kemampuan individu mengontrol 
PSISULA: Prosiding Berkala Psikologi

Vol. 1, 2019

E-ISSN: 2715-002X

impuls/dorongan yang kuat; (c) Optimism, mempunyai harapan dan percaya bahwa kehidupan mereka dapat berubah menjadi lebih baik; (d) Causal analysis, kemampuan individu untuk mengidentifikasi secara akurat tentang penyebab dari permasalahan yang sedang mereka hadapi dalam kehidupan; (e) Empathy, kemampuan individu untuk mengetahui tanda/isyarat psikologis atau emosional yang diperlihatkan oleh orang lain; (f) Self Eficacy, menggambarkan keyakinan seseorang bahwa individu dapat memecahkan masalah yang dialaminya dan keyakinan seseorang terhadap kemampuannya untuk mencapai kesuksesan; (g) Reaching Out, kemampuan seseorang untuk mencapai keberhasilan.

\section{Metode penelitian}

Penelitian ini merupakan penelitian deskriptif yang hanya melibatkan satu variable mandiri, yaitu resiliensi. Subjek dari penelitian ini adalah staf lapangan dari sebuah perusahaan jasa konstruksi, meliputi: pelaksana proyek 3 orang, logistic material, logistik alat, surveyor, asisten surveyor, operator, dan mandor proyek.

Hasil penelitian dilaporkan dalam studi deskriptif berdasarkan hasil wawancara. Peneliti dalam melakukan penelitian dibantu dengan instrumen resiliensi yang merujuk pada teori Reivich dan Shatte (2002) dan menjadi pedoman untuk pengumpulan data penelitian.

\section{Hasil dan Diskusi}

Setelah dilakukan penelitian mengenai resiliensi staf lapangan perusahaan konstruksi didapatkan hasil sebagai berikut (ditinjau dari ketujuh aspek dari resiliensi):

\section{Regulasi Emosi (Emotional Regulation)}

Saat mengalami tekanan pekerjaan, subjek benar-benar sadar kalau setiap pekerjaan pasti ada deadline dan risiko. Untuk tekanan pekerjaan itu sendiri sudah otomatis ada karena manajemen dalam sebuah proyek salah satu unsurnya adalah waktu. Sehingga wajar kalau ada tekanan pekerjaan baik dari atasan ataupun dari owner.

Dipresentasikan dalam Seminar Nasional "Membangun Resiliensi di Era Revolusi Industri 4.0" 
PSISULA: Prosiding Berkala Psikologi

Vol. 1, 2019

E-ISSN: 2715-002X

Pelampiasan emosi subjek saat ada tekanan pekerjaan meliputi: membentak ke pekerja, sharing ke rekan lainnya, minum kopi, merokok, bermain media sosial. Selain itu, ada yang berusaha memberi wawasan ke pekerja, memberi pengertian kepada tukang/pekerja lainnya, dan jika ada masalah akan dibahas sampai tuntas.

Cara mengontrol emosi subjek saat ada tekanan pekerjaan biasanya dengan merokok. Hal itu dapat meredakan emosi. Kemudian, sharing dengan rekan kerja. Kebanyakan dari mereka merupakan tipikal orang yang tidak bisa memendam emosi, jadi mereka sering bercerita ke teman sesama rekan kerja. Hal itu berguna untuk mengontrol emosi mereka.

Hubungan subjek dengan orang-orang di sekitar lingkungan pekerjaan sangat baik. Perselisihan pasti ada, akan tetapi bagaimanapun juga mereka menyadari bahwa mereka makhluk sosial. Sehingga, hubungan yang terjalin dengan rekan kerja baik-baik saja. Di samping sebagai rekan kerja, subjek juga sebagai sahabat.

Reaksi subjek ketika tidak diterima kelompok karena tidak mau berkompromi, Subjek akan santai dan tetap menjalankan jobdesk yang harus dilaksanakan. Sesuai dengan pengalaman dan usia subjek, mereka tidak takut dikucilkan di pekerjaan. Hal terpenting adalah bekerja dengan tanggung jawab dan tidak takut kalau harus keluar dari pekerjaan.

\section{Kontrol Impuls (Impulse Control)}

Respon subjek saat terlintas pemikiran adanya godaan di proyek (misalnya: kecurangan, pengurangan bahan dII), subjek tetap berpegang teguh pada prinsip. Mereka tidak mau merugikan perusahaan yang telah membayar subjek. Akan tetapi, ada catatan selagi tidak merugikan perusahaan dan bisa mengefisienkan sesuatu ada lebihnya untuk anggota (hal itu boleh-boleh saja).

Tindakan subjek ketika ada rekan kerja yang menawarkan uang tips. Subjek realistis. Selagi mereka butuh mereka ambil. Dengan catatan dilihat sebesar apa resikonya. Kalau resiko terlalu tinggi, tidak akan diambil. 
PSISULA: Prosiding Berkala Psikologi

Vol. 1, 2019

E-ISSN: 2715-002X

Tindakan subjek jika ada rekan kerja yang mengajak meninggalkan lapangan sebelum waktunya tergantung pada konsisi lapamgan. Terkadang saat dibutuhkan oleh lapangan bisa sampai tidak istirahat. Tetapi jika sebelum waktu istirahat dan di lapangan sudah tidak dibutuhkan, maka dapat langsung meninggalkan lapangan untuk membeli makan dan istirahat.

\section{Optimisme (Optimism)}

Subjek memandang masa depannya sebagai seorang staf lapangan dengan optimis bisa lebih maju dalam pekerjaan konstruksi bangunan. Karena subjek yakin setiap industri pasti akan menggunakan dan membutuhkan jasa konstruksi. Subjek yakin bisa menjadi orang sukses dengan latar belakang pekerjaan di bidang jasa konstruksi. Optimisme subjek mengenai penerimaan rekan kerja atas kehadirannya di lingkungan kerja sangat yakin. Di setiap perusahaan pasti ada yang suka dan ada yang tidak suka. Hal itu wajar. Subjek juga punya banyak relasi di luar dari proyek itu. Yang terpenting dari subjek adalah mereka sudah bekerja sesuai jobdesk. Optimisme subjek menyelesaikan pekerjaan sesuai deadline sebesar $80-85 \%$. Dalam pekerjaan lapangan, hal yang paling utama adalah cashflow dan material. Jika cash dan material terpenuhi, untuk waktu akan cepat selesai tanpa harus dikejar target.

\section{Analisis Kausal (Causal Analysis)}

Jika ada suatu masalah, subjek mengidentifikasi dan mencari tau pokok permasalahannya dimana. Kemudian mencari solusi yang terbaik, bukan justru ditinggal dan melarikan diri. Kalau masalahnya berhubungan dengan teknik, berarti subjek berpedoman aturan teknik yang memang sudah baku dari pendidikan teknik di proyek, biasanya pedomannya adalah gambar yang sesuai dengan kontrak sebelumnya.

Bagi subjek gagal dalam satu hal bukan berarti gagal dalam semuanya. Kegagalan dapat dijadikan sebagai contoh ke depannya. Agar subjek tidak mengulangi lagi kesalahan-kesalahan sebelumnya karena setiap masalah pasti ada pembetulannya. Di sisi lain, subjek sepakat dengan pernyataan setiap masalah pasti ada solusinya. Tapi subjek berpendapat bahwa solusi tidak selalu mengenakkan 
PSISULA: Prosiding Berkala Psikologi

Vol. 1, 2019

E-ISSN: 2715-002X

pihak kita atau untuk semuanya. Pasti ada yang harus dirugikan. Misal yang sering dirugikan adalah waktu.

Subjek sering berdiskusi dengan rekan kerja tentang permasalahan yang dihadapi. Namun apabila masalah bisa diatasi sendiri mereka memilih untuk diam. Akan tetapi jika masalahnya bersama akan lebih baik jika didiskusikan bagaimana baiknya. Jika dipendam sendiri yang ada masalah tidak selesai dan menambahi beban subjek. 
PSISULA: Prosiding Berkala Psikologi

Vol. 1, 2019

E-ISSN: 2715-002X

\section{Empati (Empathy)}

Ketika rekan kerja mengalami kesulitan/kesusahan di kehidupan keluarganya dan membutuhkan bantuan, subjek sebisa mungkin akan menolong nya. Karena bagaimanapun juga mereka saling membutuhkan satu sama lain, sehingga membantu adalah sebuah kewajiban bagi mereka. Subjek tetap membantu rekan kerja yang mungkin tidak disukainya karena sifat atau kelakuannya. Harapannya adalah semoga dengan perlakuan kita terhadap mereka, orang tersebut dapat berubah sikap dan perlakuannya yang tidak baik tersebut.

Pandangan rekan kerja terhadap subjek adalah sosok yang baik dan dapat membantu rekan kerja saat kesusahan. Selain itu bisa dijadikan tempat sharing, tempat curhat bagi masing-masing rekan kerja tersebut. Kalau masalah membaca emosional rekan kerja bagi subjek sudah pengalaman. Karena subjek sudah lama bergabung di dunia kontraktor. Subjek sudah terbiasa melihat dan membaca perkataan orang dari mimik wajah seseorang.

\section{Efikasi Diri (Self-Efficacy)}

Subjek memandang dirinya sebagai sosok yang santai dan pekerja keras. Kalau pada kemampuan di bidang teknik sipil sudah baik. Mungkin ada beberapa kendala di dalam bidang teknologi informasinya. Karena faktor usia, sehingga kemampuan untuk berteknologi masih kurang.

Keyakinan subjek melakukan pekerjaan dengan baik walaupun tertekan oleh keadaan tergantung pada faktor usia. Bagi yang sudah berusia hampir setengah abad cenderung bisa memilah dan membedakan mana kewajiban/tanggung jawab dan pribadi. Kemudian, untuk yang berusia masih muda cenderung masih sering kepikiran dan bisa sampai tidak masuk kerja karena masalahnya.

\section{Reaching Out}

Subjek mempelajari suatu masalah dalam pekerjaan, jika mereka jatuh mereka akan dan harus bangkit lagi. Permasalahan yang terjadi itu rata-rata dikarenakan sikap kurang hati dari manusia dan kadang sering tidak fokus pada pekerjaan dan kurang koordinasi antar komponen yang terkait. 
PSISULA: Prosiding Berkala Psikologi

Vol. 1, 2019

E-ISSN: 2715-002X

Rata-rata subjek menginginkan kehidupan sederhana. Yang penting tercukupi sandang, pangan dan papannya membuat keluarga senang. Kemudian ada juga yang berkeinginan untuk tidak terus menerus bekerja pada orang lain. Subjek ingin mendirikan usaha sendiri, baik di bidang konstruksi maupun di bidang lainnya.

Pandangan subjek mengenai kegagalan-kegagalan yang pernah dialaminya. Kegagalan adalah guru terbesar dalam hidup. Subjek punya kewajiban berusaha dan doa. Di samping itu, harapan subjek dengan jobdesk/tugas pekerjaan yang banyak dapat terselesaikan dengan baik. Meski ada halangan dan rintangan dalam proyek setidaknya masalah dalam job tetap terselesaikan. Di sisi lain, agar atasan juga puas dengan kinerja kita dan dapat menguntungkan ke depannya.

Subjek berani dalam mengatasi ketakutan yang mengancam pekerjaan karena sudah mengerti apa itu risiko. Intinya berani berbuat harus berani bertanggung jawab. Bagi subjek dalam masalah gaji, itu tidak masalah kalau memang layak di potong ya harus di potong bahkan kalau memang subjek tidak bisa hadir 100\% dan tidak digaji, mereka tetap bertanggung jawab dengan cara komunikasi ke pekerja, mandor atau bagian administrasi/kantor.

Berdasarkan pernyataan-pernyataan di atas, subjek penelitian bisa dikatakan merupakan individu yang resilien. Dimana ada lebih dari satu aspek yang dimiliki oleh subjek, diantaranya: aspek emotional regulation, causal analysis, dan emphaty.

Regulasi emosi mengajarkan bagaimana mengidentifikasi dan menggambarkan emosi, bagaimana mengurangi kerentanan terhadap emosi negatif dan meningkatkan emosi positif. Individu yang mampu meregulasi emosi berarti mampu memodifikasi emosi negatif karena pengalaman-pengalaman yang buruk hingga mendapatkan emosi yang positif untuk meraih keseimbangan di dalam emosi. Orang yang resilien bisa mengendalikan emosi mereka, terutama dalam menghadapi tantangan atau kesulitan, untuk tetap fokus pada tujuan (Reivich \& Shatte dalam Sukmaningpraja).

Sebuah penelitian oleh Tugade \& Fredrickson (2007) menunjukkan regulasi emosi yang menghasilkan emosi positif sangat membantu dalam membangun 
PSISULA: Prosiding Berkala Psikologi

Vol. 1, 2019

E-ISSN: 2715-002X

resiliensi seseorang pada situasi stres. Hasil penelitian ini juga diperkuat oleh Rizki (2010) yang menemukan bahwa regulasi emosi mempunyai hubungan signifikan dengan resiliensi. Regulasi emosi mempunyai strategi dimana strategi dalam regulasi emosi tersebut dapat membangun resiliensi yang baik.

Gottman (1997) menunjukkan bahwa dengan mengaplikasikan regulasi emosi dalam kehidupan berdampak positif baik dalam kesehatan fisik, keberhasilan akademik, kemudahan dalam membina hubungan dengan orang lain dan meningkatkan resiliensi. Hasil penelitian yang menunjukkan hubungan positif dimungkinkan karena aspek regulasi emosi berkaitan dan memiliki pengaruh pada aspek-aspek resiliensi. Selain itu kemampuan meregulasi emosi menyebabkan individu memiliki keyakinan pada diri sendiri, kemampuan untuk bergantung pada diri sendiri dan menyadari kekuatan serta keterbatasan diri (Widuri, 2012).

Individu yang resilien, memiliki kemampuan untuk mengkontrol emosi, tingkah laku dan atensi dalam menghadapi masalah. Sebaliknya individu yang memiliki kesulitan dalam regulasi emosi sulit untuk beradaptasi, menjalin relasi dengan orang lain dan mempertahankan hubungan yang telah terjalin dengan orang lain. Individu yang memiliki kesulitan untuk meregulasi emosi cenderung untuk terjebak dalam emosinya dan pada akhirnya sulit untuk membuat keputusan dengan tepat, menghadapi permasalahan dalam hidupnya dengan positif, serta tidak terbuka pada pengalaman baru (Widuri, 2012). Oleh sebab itu, subjek penelitian ini memiliki aspek regulasi emosi dan causal analysis karena keduanya saling berhubungan.

Di samping itu, penelitian Widuri (2012) menyatakan bahwa individu yang memiliki kontrol impuls yang tinggi akan memiliki regulasi emosi yang tinggi pula. Ketika seseorang tidak mampu mengkontrol impuls, ia akan menerima belief yang pertama kali muncul pada dirinya tanpa mempertimbangkan hal lainnya. Akibatnya ia akan percaya setiap kejadian negatif dan berlaku sesuai dengan beliefnya. Namun demikian, hasil temuan ini cukup menarik, karena kontrol impuls pada dasarnya berkaitan erat dengan kemampuan regulasi emosi. Pada penelitian ini ditemukan subjek kurang bisa mengendalikan impuls/godaan di proyek. 
PSISULA: Prosiding Berkala Psikologi

Vol. 1, 2019

E-ISSN: 2715-002X

Selain pengendalian impuls, subjek penelitian ini kurang bersikap optimis dalam menyelesaikan tekanan pekerjaan. Hal ini dikarenakan ada factor lain yang mempengaruhi kelancaran suatu proyek. Factor tersebut adalah material dan cash/biaya. Subjek sangat yakin dan optimis dengan kemampuan yang mereka miliki. Akan tetapi tidak dapat dipungkiri juga apabila material telat didatangkan dan cash yang kurang. Oleh sebab itu, perlu dibutuhkan manajemen yang solid di dalam dunia proyek demi kelancaran sebuah proyek.

Untuk aspek keyakinan diri dari subjek masih tergolong kurang. Hal ini sangat berkaitan dengan optimisme subjek. Apabila subjek kurang optimis otomatis mereka tidak yakin pada diri mereka. Dan apa yang akan dicapai ke depannya juga menjadi kurang maksimal. Prihastuti (2011) menyatakan bahwa faktor Optimism pada dasarnya berkaitan erat dengan faktor Self-Efficacy. Selfefficacy menggambarkan keyakinan seseorang bahwa ia dapat memecahkan masalah yang dialaminya dan keyakinan seseorang terhadap kemampuannya untuk mencapai kesuksesan. Individu yang optimis akan memotivasi dirinya untuk menyelesaikan suatu masalah dan memperbaiki situasi.

\section{Kesimpulan}

Berdasarkan hasil dan diskusi penelitian menunjukkan bahwa subjek dalam penelitian ini memiliki sikap resilien terutama dalam hal emotional regulation, causal analysis, dan emphaty. Akan tetapi, subjek masih kurang bisa mengendalikan impuls dalam proyek, kemudian kurang optimis dalam menyelesaikan pekerjaan dikarenakan ada faktor lain yang mempengaruhi kelancaran suatu proyek, dalam hal ini material proyek. Di samping itu subjek juga masih kurang dalam efikasi diri dan pencapaian diri mereka ke depannya. 
PSISULA: Prosiding Berkala Psikologi

Vol. 1, 2019

E-ISSN: 2715-002X

\section{Daftar Pustaka}

Atmaji, L. (2011). Pengaruh Stres Kerja dan Kepuasan Kerja Terhadap Kinerja Perawat (Studi Pada Rumah Sakit Islam Sultan Agung Semarang). Semarang: Universitas Diponegoro.

Desmita. (2005). Psikologi Perkembangan. Bandung: PT Remaja Rosdakarya.

Gottman, J. (1997). Raising an Emotionally Intelligent Child: The Heart of Parenting. New York : Rockefeller Center.

Mappijatim.or.id/ragam-berita/lewati-deadline-42-rekanan-pemkot-surabaya-kenablacklist.html, diakses pada tanggal 09 September 2019, (http://www.mappijatim.or.id/ragam-berita/lewati-deadline-42-rekananpemkot-surabaya-kena-blacklist.html)

Martel, J. (2005), "Mental Health at Work from defining to solving the problem". Occupational Health and Safety Managementat Universite Laval, Quebec, Canada

McCubbin, H. I., Thompson, A. I., \& McCubbin, M. A. (2001). Family Measures: Stres, Coping \& Resiliency. Honolulu Hawai: Kamehameha Schools

Nusa7.com/7-resiko-umum-kontraktor-jasa-konstruksi-sebelum-smk3/, diakses pada tanggal 09 September 2019, (http://nusa7.com/7-resiko-umumkontraktor-jasa-konstruksi-sebelum-smk3/)

Prasetyono, P. N. (2015). Faktor Penyebab Stres Kerja Karyawan Kontraktor di Surabaya. Surabaya: Institut Teknologi Sepuluh Nopember.

Prihastuti. (2011). Profil Resiliensi Pendidik Berdasarkan Resilience Quetient Test. Jurnal Penelitian dan Evaluasi Pendidikan, 15(2), 199-214. DOI: 10.21831/pep.v15i2.1102

Purwanty, L.R., \& Utomo, C (2011), "Faktor-Faktor Yang Mempengaruhi Kinerja SDM Dalam Perawatan Gedung Kantor Di Lingkungan Pemerintah Kota Pangkalpinang", Prosiding Seminar Nasional Manajemen Teknologi XIII, Program Studi MMT-ITS, Surabaya 5 Pebruari 2011.

Rachman, I.B., \& Utomo, C. (2011), “Perbandingan Sistem Pemberian Upah Harian Dengan Upah Borongan Terhadap Produktivitas Buruh Konstruksi 
PSISULA: Prosiding Berkala Psikologi

Vol. 1, 2019

E-ISSN: 2715-002X

Pada Kontraktor Di Surabaya", Prosiding Seminar Nasional Manajemen Teknologi XIII, Program Studi MMT-ITS, Surabaya 5 Pebruari 2011.

Reivich, K., \& Shatte, A. (2002). The resilience factor: 7 keys to finding your inner strength and overcoming life's hurdles. New York: Broadway Books.

Republika.co.id. 2013, diakses pada tanggal 09 September 2019, (https://www.republika.co.id/berita/nasional/umum/13/01/15/mgo5o9-sektorjasa-konstruksi-sumber-kecelakaan-kerja-tertinggi-di-indonesia)

Rizki, B. M. (2010). Hubungan antara Strategi Regulasi Emosi dan Factor Demografi dengan Resiliensi pada Perempuan Narapidana. Yogyakarta: Universitas Gadjah Mada.

Robbins, S.P., \& Judge, T.A. (2011), "Perilaku Organisasi Organizational Behavior". Jakarta: Penerbit Salemba Empat Edisi 12.

Sawitri, P., Adihardjo, R.B., \& Utomo, C. (2007), “Analisis Terhadap Model Pengaruh Kepuasan Bekerja Dan Komitmen Berorganisasi Pada Kinerja (Studi Terhadap Tenaga-Tenaga Ahli Konsultan Perencanaan Dan Pengawasan Jalan Dan Jembatan Di Jawa Timur)", Prosiding Seminar Nasional Manajemen Teknologi $V$, Program Studi MMT-ITS, Surabaya 3 Pebruari 2007

Septiani, T., \& Fitria, N. (2016). Hubungan antara Resiliensi dengan Stres pada Mahasiswa Sekolah Tinggi Kedinasan. Jurnal Penelitian Psikologi. 07(02), 59-76.

Sukmaningpraja, A., \& Santhoso, F. H. (2016). Peran Regulasi Emosi terhadap Resiliensi pada Siswa Sekolah Berasrama Berbasis Semi Militer. Journal of Psychology, 02(03), 184-191. ISSN: 2407-7798

Tugade, M. M., \& Fredrickson, B. L. (2007). Regulation of positive emotion: Emotion regulation strategies that promote resilience. Journal of Happiness Studies, 311333

Widuri, E.L. (2012). Regulasi Emosi Dan Resiliensi Pada Mahasiswa Tahun Pertama. Jurnal Humanitas, 9(2) 